\title{
Tenure and academic deadwood
}

\author{
Nikolaos Nikolioudakis ${ }^{1}$, Athanassios C. Tsikliras ${ }^{2}$, Stylianos Somarakis ${ }^{1}$, \\ Konstantinos I. Stergiou ${ }^{1,2, *}$ \\ ${ }^{1}$ Institute of Marine Biological Resources and Inland Waters, Hellenic Centre for Marine Research, Aghios Kosmas, \\ 16777 Athens, Greece \\ ${ }^{2}$ Department of Zoology, School of Biology, Aristotle University of Thessaloniki, UP Box 134, 54124 Thessaloniki, Greece
}

\begin{abstract}
The introduction of market forces into higher education (i.e. marketization) in recent decades goes along with a sharp decline in tenured positions offered, accompanied by polemic voices against tenure. The main claim, that tenure reduces the productivity of senior faculty, has not been thoroughly tested, with existing scarce evidence being controversial. We tested this hypothesis by analyzing the number of publications of 2136 currently full professors of natural sciences, drawn from 123 universities distributed in 15 countries, during the period 1996 to 2014. Our results showed that long-term productivity of full professors increased, irrespectively of subject field, geographic area, and university rank. This suggests that tenure does not lead to motivation loss and academic deadwood. Our results have policy, academic, and ethical implications related to human resource management, academic freedom, and educational quality, and tenure polemicists should find an argument other than lowered post-tenure productivity to support their stand.
\end{abstract}

KEY WORDS: Full professor $\cdot$ Productivity $\cdot$ Number of publications $\cdot$ Motivation $\cdot$ Natural sciences

\section{INTRODUCTION}

Globally, education is the largest market after healthcare, with a total expenditure in 2012 of over US\$ 4 trillion and forecasted expenditure for 2017 of over US\$ 6 trillion (GSV Advisors 2012, BIS 2013). This and the sharply increasing rise in international students, who numbered over 4.2 million in 2010 (Robinson 2014), have greatly contributed to the marketization of higher education during the last couple of decades in several countries (Amsler 2014, Lynch 2014). Marketization has been hypothesized (Stergiou \& Tsikliras 2014) to drive the strong decline in the number of tenured positions in the last decades, e.g. in the USA, UK, and Germany (Karran 2007, Kaplan 2010). This situation might have fueled the debate on tenure, which is as old as tenure itself (Holley 1977) and attracts the media (Pager 2013), as suggested by the recent appearance of strong, often polemic, voices against it (e.g. Kaplan 2010, Riley 2012, Wetherbe 2012, 2013, Bruni 2014, Peterson 2014). Undoubtedly,

*Corresponding author: kstergio@bio.auth.gr a change in tenure policy requires one or more arguments, as Allen (2000, p 99) implied when mentioning that '[c]ritics have long assailed tenure with little more than bogus arguments and specious evidence.' One such argument against tenure, easily accepted by the public, is that tenure causes low productivity (Allen 2000, Antony \& Hayden 2009, Kaplan 2010). This is well described by Kaplan (2010, p 124): 'Critics of tenure in the United States and Europe say that it ... allows senior faculty members to become unproductive and complacent.' Yet, this belief has not been confirmed (Allen 2000), and the slight evidence from the 'tenure literature' either supports (Katz 1973, Holley 1977, Levin \& Stephan 1991, Hammermesh 1994, Harrison 2006, Leung 2009, Estes \& Polnick 2012) or rejects it (Bonzi 1992).

Herein we tested the hypothesis that tenure leads to reduced long-term productivity of senior faculty members (full professors) in the natural sciences by analyzing their annual number of publications, typically considered to reflect academic productivity

() The authors 2015. Open Access under Creative Commons by Attribution Licence. Use, distribution and reproduction are unrestricted. Authors and original publication must be credited. 
(Petersen et al. 2010), during the period 1996 to 2014. We considered that if there was an increasing trend in the annual number of publications, irrespective of when tenure was granted, the hypothesis that tenure reduces productivity can be rejected.

\section{MATERIALS AND METHODS}

We studied trends in the publication records of full professors (i.e. those listed as 'full professors' on the web pages of their departments) because they, as opposed to associate and assistant professors, do not have to undergo any further institutional evaluation for promotion. The studied sample was drawn from 123 universities in 15 countries (i.e. Australia, Canada, Denmark, Finland, France, Germany, Greece, Italy, Netherlands, New Zealand, Norway, Poland, Spain, UK, USA) within 3 large geographical regions (North America, Europe, and Oceania). We restricted our analysis to natural sciences and used all subject fields of natural sciences included in the worldwide university rankings of the Quacquarelli Symonds (QS) company (www.topuniversities.com/subject-rankings/ 2015): biological sciences, chemistry, geography \& area studies, mathematics, and physics \& astronomy. We selected the universities randomly from the rankings per subject field lists provided by QS in order to achieve a broad representation from high, middle, and lower ranked universities (see Appendix 1) and thus to exclude any bias related to university quality (Neumann 1979). In the case of the lower ranked universities (i.e. with ranks from 175 to 200), for the 5 studied subject fields, when the selected universities did not provide the rank of their faculty members (i.e. full professor, associate professor, assistant professor, or lecturer) on their web pages, we had to randomly select universities outside of the QS subject field list. These universities were classified as rank $>200$. Subsequently, 2136 full professors were randomly drawn from the selected universities, and their publication records were downloaded from Elsevier's Scopus database (www.scopus.com/).

We selected the Scopus database mainly because its available tools make the downloading of the annual publication records for each author very practical. Although the number of publications provided by Scopus extends in some cases back to 1950, we used data from 1996 to 2014 because Scopus citation tracking is only available for publications from 1996 to present (Burnham 2006), and coverage for several fields (e.g. mathematics, social sciences) before 1996 is considered weak (Bosman et al. 2006).
To study the productivity of tenured professors, we tested for a significant increasing trend in the number of publications over time. We considered that if the annual number of publications exhibited an increasing trend during 1996 to 2014, irrespective of when tenure was granted during this period, the hypothesis that tenure reduces productivity can be rejected. Initially, 3 different models (linear, power, and exponential) were fitted to the publications of each professor with time and the best fit was judged in terms of model fit significance and the value of the coefficient of determination $\left(r^{2}\right)$. Additionally, the visual inspection of residuals was used to verify the suitability of the best fit selected in each case. Subsequently, for the exploration of general trends, we calculated the mean number of publications per year (and their associated standard errors) for: (1) the pooled data (i.e. irrespectively of scientific field and geographic area), (2) for each geographic area (i.e. North America, Europe, and Oceania), and (3) for each subject field. We then fitted a regression to the mean number of publications vs. years.

\section{RESULTS}

On an individual basis, we found a significant positive trend (either linear, or power or exponential) in the number of publications $\mathrm{yr}^{-1}$ for 885 $(41.43 \%)$ out of the 2136 professors analyzed (Table 1). For the remaining $1251(58.57 \%)$ professors, there was no significant $(\mathrm{p}>0.05)$ positive or negative trend. Yet, for 771 professors, out of the 1251 with no significant positive or negative trend, the linear slope was positive, and for 480 professors it was negative.

Our results clearly showed that across geographical areas, subject fields, and university ranks (QS

Table 1. Summary report of the model (linear, exponential, or power) fit for each professor's annual publications vs. time (for the period 1996 to 2014)

\begin{tabular}{|lcc|}
\hline Model fit & Model & $\begin{array}{c}\text { No. of professors } \\
\text { (\% of total) }\end{array}$ \\
\hline $\begin{array}{l}\text { Significant trend in } \\
\text { publications yr }\end{array}$ & Any fit & $885(41.43)$ \\
& Linear & $244(11.42)$ \\
& Exponential & $352(16.48)$ \\
Non-significant trend & Power & $289(13.53)$ \\
Sum & & $1251(58.57)$ \\
& & $2136(100.0)$ \\
\hline
\end{tabular}


worldwide university ranking system), the mean annual number of publications per professor increased significantly over time, with rates of increase varying with area and discipline (see Figs. 1-3). Overall, across all subject fields, the mean number of publications per year almost doubled between 1996 and 2014, increasing from $3.01 \pm 0.09$ (mean \pm SE) in 1996 to $5.63 \pm 0.19$ in 2014 (Fig. 1A). Similarly, the mean number of publications per year almost doubled during 1996 to 2014 for all 3 geographic regions examined, increasing from $3.28 \pm 0.14$ to $5.42 \pm 0.27$ for North America (Fig. 1B), from $2.63 \pm 0.12$ to $5.74 \pm$ 0.27 for Europe (Fig. 1C), and from $3.67 \pm 0.44$ to 7.85 \pm 0.58 for Oceania (Fig. 1D). The rate of increase was lower in North America (0.164) and higher in Oceania $(0.243$; Fig. 1B,D).

The mean number of publications also almost doubled during 1996 to 2014 for all 5 disciplines; it increased from $2.68 \pm 0.11$ to $4.76 \pm 0.16$ for biological sciences (Fig. 2A), from $4.86 \pm 0.32$ to $7.81 \pm 0.42$ for chemistry (Fig. 2B), from $1.51 \pm 0.13$ to $3.19 \pm 0.22$ for geography \& area studies (Fig. 2C), from $1.55 \pm 0.10$ to $2.75 \pm 0.19$ for mathematics (Fig. 2D), and from $4.86 \pm 0.32$ to $10.94 \pm 0.95$ for physics \& astronomy (Fig. 2E). The slope was shallower for mathematics
(0.084) and steeper for physics \& astronomy $(0.462$; Fig. 2D,E). The large increase in the average number of articles observed in 2012 in the field of physics $\&$ astronomy can be attributed to the numerous publications that Conseil Européenne pour la Recherche Nucléaire (CERN) experiments produced (http:// library.web.cern.ch/annual/list-cern-publications2012). It is noteworthy that in the examined dataset, 14 professors of physics \& astronomy had published over 100 journal articles in 2012, whereas only 3 of them passed the 100-article threshold in 2013, leading to a drop in the average number of papers in the field in 2013.

The mean number of publications also significantly increased for universities of different ranks; it increased from $3.19 \pm 0.17$ to $6.18 \pm 0.28$ for the QS 1-50 class (i.e. universities ranked at positions 1 to 50) (Fig. 3A), from $2.98 \pm 0.19$ to $5.37 \pm 0.41$ for the QS 51-100 class (Fig. 3B), from $2.77 \pm 0.18$ to $5.00 \pm 0.36$ for the QS 101-150 class (Fig. 3C), from $2.98 \pm 0.21$ to $5.94 \pm 0.57$ for the QS 151-200 class (Fig. 3D), and from $2.73 \pm 0.22$ to $4.21 \pm 0.48$ for the $\mathrm{QS}>200$ class (Fig. 3E). The slope was shallower for the $>200$ class (0.123) and steeper for the 151-200 class $(0.202$; Fig. 3D,E).
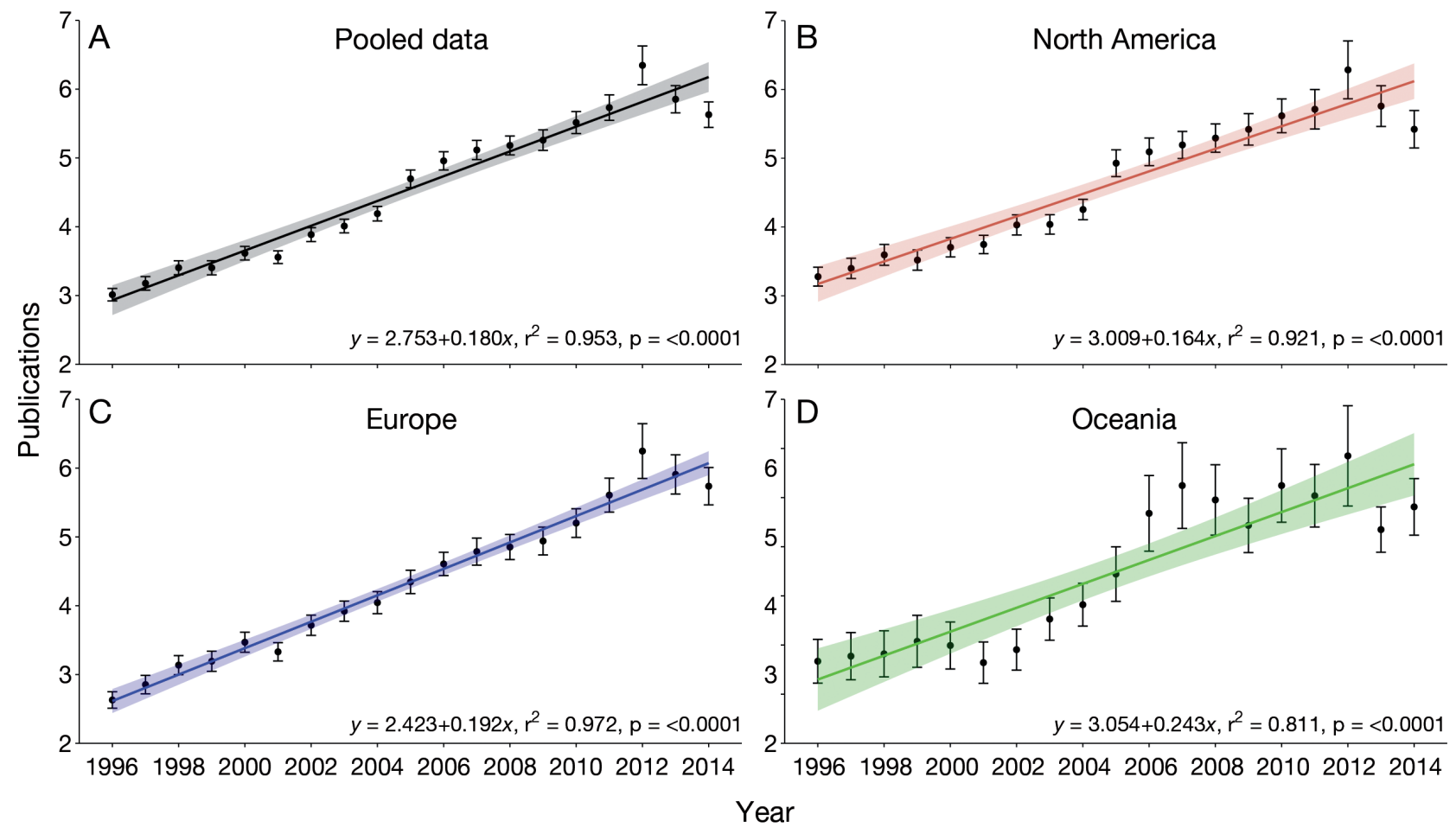

Fig. 1. Relationship between the mean $( \pm$ SE) number of publications per full professor (n) vs. year, for the period 1996 to 2014 . (A) Total pooled data, $\mathrm{n}=2136$, and (B-D) by region: (B) North America, $\mathrm{n}=1090$; $(\mathrm{C})$ Europe, $\mathrm{n}=940$; (D) Oceania, $\mathrm{n}=106$. Fainted ribbon represents the $95 \%$ confidence intervals of the regression line 

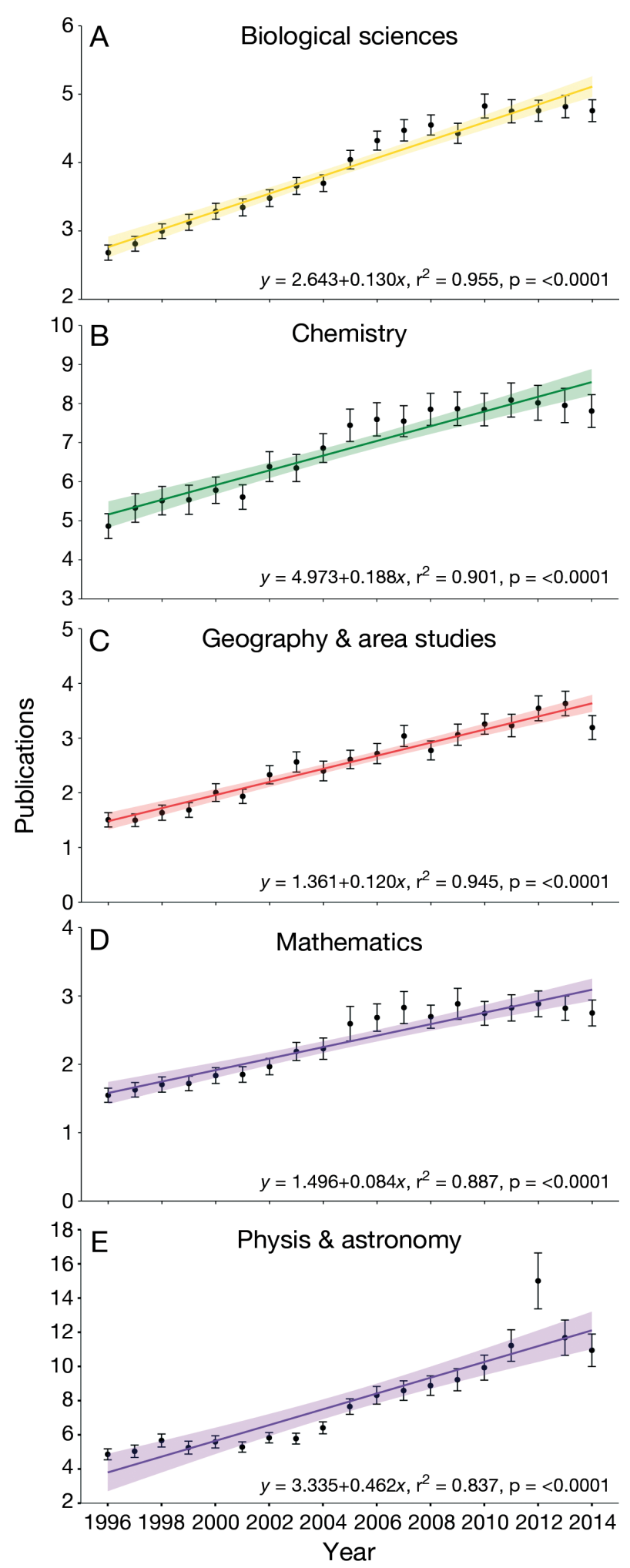

Fig. 2. Relationship between the mean $( \pm \mathrm{SE})$ number of publications per full professor (n) vs. year, for the period 1996 to 2014, by subject field in natural sciences. (A) Biological sciences, $\mathrm{n}=819$; (B) chemistry, $\mathrm{n}=343$; (C) geography $\&$ area studies, $\mathrm{n}=261$; (D) mathematics, $\mathrm{n}=389$; $(\mathrm{E})$ physics \& astronomy, $\mathrm{n}=324$. Fainted ribbon represents the $95 \%$ confidence intervals of the regression line
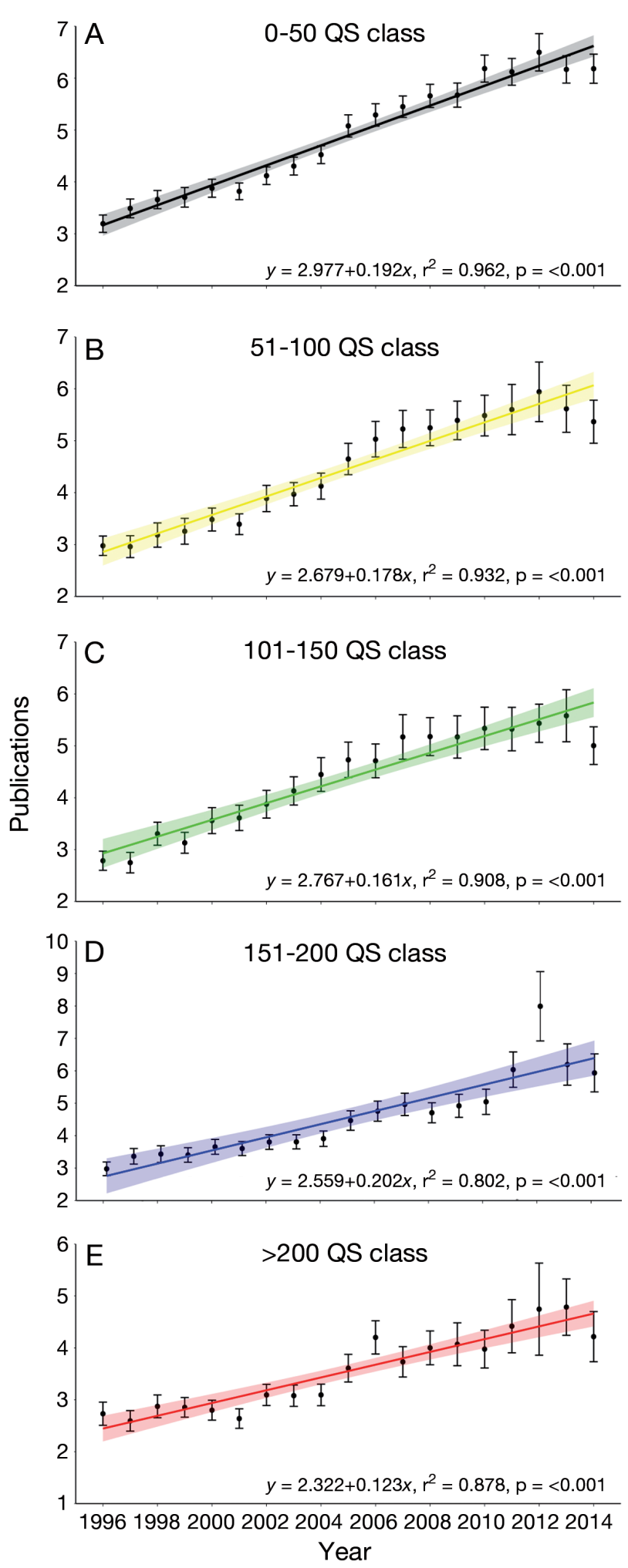

Fig. 3. Relationship between the mean $( \pm \mathrm{SE})$ number of publications per full professor (n) vs. year, for the period 1996 to 2014 , by worldwide university ranking categories of the Quacquarelli Symonds (QS) company. (A) QS class 1-50 (i.e. universities ranked at positions 1 to 50 ), $\mathrm{n}=842$; (B) QS class 51-100, $\mathrm{n}=398$; (C) QS class 101-150, $\mathrm{n}=304$; (D) QS class 151-200, $\mathrm{n}=388$; (E) QS class $>200, \mathrm{n}=204$. Fainted ribbon represents the $95 \%$ confidence intervals of the regression line 


\section{DISCUSSION}

The debate of how tenure affects faculty productivity is as old as tenure itself (Holley 1977) and has been at the heart of the tenure debate (Faria \& McAdam 2014; see also Allen 2000 for other aspects of the debate). Although tenure has different forms in different countries, the common denominator is the long-term job security for academics (Karran 2007). The reasoning behind the belief that productivity declines, or even vanishes, after tenure (Henry 1980, Finkelstein \& Schuster 2001) is that academics, once tenured, lose motivation for publications and research because of the long-term job security (Bess 1998, Estes \& Polnick 2012). Supporting evidence comes from physics and earth sciences (Levin \& Stephan 1991), sociology (Holley 1977), economics (Hammermesh 1994, Leung 2009), law (Harrison 2006), and education (Estes \& Polnick 2012). Nevertheless, an analysis of data on faculty from economics, electrical engineering, English, French, history, mathematics, physics, political science, psychology, sociology, and zoology showed that publication records of tenured faculty only decline temporarily, right after tenure is granted (Katz 1973).

Our results reject the hypothesis that tenure leads to lower long-term productivity, at least in natural sciences. This agrees with other studies, which however are limited in number and in terms of sample size (science, humanities, social sciences: Bonzi 1992). The observed increase in productivity (Figs. 1-3, Table 1) could be attributed to the synergistic action of different factors. Firstly, motivation and competition (Allen 2000), as well as building of reputation (Rees \& Smith 1991) that attracts students and thus leads to increased lab sizes, lobbying (Bauer 2004), and the wish to increase their influence over other faculty members, over time all drive tenured professors to be productive. Additionally, research and publication habits of tenure-track faculty persist after tenure (Faria \& Monteiro 2008), a fact explaining why early-career productivity is often used to predict overall productivity (Bonzi 1992, Laurance et al. 2013). Finally, job satisfaction (Pain 2015), resulting not only from job security but also from other benefits associated with tenure, e.g. lab facilities, creates the necessary landscape for productivity and innovation. All the above support the findings of studies showing that tenured faculty are more productive than non-tenured (physical therapy: Kaufman 2007; National Survey of Postsecondary Faculty: Antony \& Hayden 2009; humanities, social sciences, natural sciences, engineering and technology, medicine: Rørstad \& Aksnes 2015).
Our results have ethical, policy, and academic implications. Undoubtedly, tenure is relatively expensive. For instance, tenured full professors in the US have an average salary ranging from US\$ 90300 to 198400 (Tsikliras et al. 2014) as opposed to average salaries from US\$ 63993 to 99781 for non-tenured full teaching professors and from US\$ 80365 to 116555 for non-tenured full research professors (CUPA-HR 2013). Thus, within the neo-liberal landscape of the marketization of education (e.g. Lynch 2014), replacing tenured faculty with non-tenured would reduce staff costs for universities and provide administrative flexibility. Under such a scenario, the argument that tenure leads to poor productivity (and poor teaching performance, which is also used as an argument against tenure, e.g. Riley 2012) provide an excellent alibi for lowering the tenured:non-tenured faculty ratio. Our results demonstrate that tenure is not associated with academic deadwood, at least regarding publications in natural sciences. Ethics-wise, those writing against tenure should find a better argument, other than lowered post-tenure productivity, to oppose it. One might further hypothesize that teaching performance will improve for tenured faculty, due to their accumulated teaching experience and the dissemination of the new knowledge produced by them (Figs. 1-3). Although teaching hours and service to students are increased for tenured compared to non-tenured faculty (Antony \& Hayden 2009), the effect of tenure on teaching performance remains to be proven quantitatively (notwithstanding the fact that teaching performance is very hard to quantify, e.g. Stergiou \& Lessenich 2014, Stratilatis 2014).

Policy-wise, instead of lowering the budget allocated to tenured faculty, university administrations could alternatively employ more flexible human resource management strategies, e.g. assigning more administrative and teaching duties to underperforming tenured professors (Harrison 2006), forcing their transformation from academic deadwood to academic driftwood. This, along with the establishment of rewards and incentives for improved performance, will most likely prevent marginalization of the underperforming tenured faculty (Ayres et al. 2003). This reshuffling of duties is in agreement with the fact that, in general, time allocated to teaching, research, administration, service to society (Antony \& Hayden 2009), editorial work, and consulting changes during the career of faculty members. Moreover, under a global labor perspective, decreasing the number of tenured positions is also against the latest proposals of the International Labour Organization on increasing permanent positions worldwide (ILO 2015). 
As our study shows, tenure is not a barrier to academic productivity. As other authors have shown, it is also not an enemy of higher education (Anonymous 1997, Allen 2000) but an aid in the search for truth, creative stability (Allen 2000), and academic novelty and excellence, leading to a high value-added outcome (Horn 2009, Pain 2015). Most importantly, tenure helps to ensure academic freedom, the backbone of the higher-education system (Nelson 2010, Pauly 2015). Tenure will continue to be a guarantee of the above-mentioned values, because '[i]mperfect as it is, unfair as it may to some seem to be, tenure in its present form serves the long-term interests of universities and society better than any alternative that has been proposed' (Horn 2009, p. 9).

Acknowledgements. This work was not supported by any grant. We thank 3 anonymous reviewers for their comments and suggestions.

\section{LITERATURE CITED}

Allen HL (2000) Tenure: why faculty, and the nation, need it. NEA Higher Ed J 16:95-110

Amsler S (2014) University ranking: a dialogue on turning towards alternatives. Ethics Sci Environ Polit 13:155-166

Anonymous (1997) Public higher education and productivity: a faculty voice. Faculty senates and faculty unions of the State University of New York and the California State University www.calstate.edu/AcadSen/Records/Reports/ VoiceOfFaculty.shtml

Antony JS, Hayden R (2009) Are tenured faculty slackers? Academic Matters Oct/Nov 2009:17-21

Ayres J, Brown P, Doering O, Harper W, Larson J, Rose S, Stauffacher C (2003) Building a foundation for career long faculty development at Purdue university. A report on post-tenure review and faculty development. University Senate Faculty Affairs, Focus Group Project Report. Available at www.purdue.edu/senate/docs/feedback/ faculty.pdf

Bauer HH (2004) Science in the 21st century: knowledge monopolies and research cartels. J Sci Explor 18:643-660

Bess J (1998) Contract systems, bureaucracies, and faculty motivation: the probable effects of a no-tenure policy. J Higher Educ 69:1-22

BIS (Department for Business, Innovation and Skills) (2013) International education, global growth and prosperity: an accompanying analytical narrative. Available at www. gov.uk/government/uploads/system/uploads/attachment_ data/file/340600/bis-13-1081-international-educationglobal-growth-and-prosperity-revised.pdf (accessed on 19 June 2015)

Bonzi S (1992) Trends in research productivity among senior faculty. Inf Process Manag 28:111-120

Bosman J, van Mourik I, Rasch M, Sieverts E, Verhoeff H (2006) Scopus reviewed and compared. The coverage and functionality of the citation database Scopus, including comparisons with Web of Science and Google Scholar. Available at http://dspace.library.uu.nl/bitstream/
handle/1874/18247/Scopus \%20doorgelicht $\% 20 \% 26 \%$ 20vergeleken \%20-\%20translated.pdf?sequence=1 (accessed 17 Nov 2015)

Bruni F (2014) The trouble with tenure. New York Times, 18 August 2014. Available at www.nytimes.com/2014/08/ 19/opinion/frank-bruni-the-trouble-with-tenure.html?_r $=0$ (accessed on 25 May 2015)

Burnham JF (2006) Scopus database: a review. Biomed Digit Libr 3:1

CUPA-HR (College and University Professional Association for Human Resources) (2013) Faculty in higher education salary survey for the 2012-2013 academic year. Available at https://www.cupahr.org/surveys/files/salary2013/AHE 13-Executive-Summary.pdf (accessed on 25 May 2015)

Estes B, Polnick B (2012) Examining motivation theory in higher education: an expectancy theory analysis of tenured faculty productivity. Int J Manag Bus Adm 15:1-7

Faria JR, McAdam P (2014) Does tenure make researchers less productive? The case of the 'specialist'. Discussion Papers in Economics. DP 05/14. Department of Economics, University of Surrey, Guildford

Faria JR, Monteiro G (2008) The tenure game: building up academic habits. Jpn Econ Rev 59:370-380

Finkelstein M, Schuster J (2001) Assessing the silent revolution: how changing demographics are reshaping the academic profession. AAHE Bull 54:3-7

GSV (Global Silicon Valley) Advisors (2012) Education sector factbook 2012. Available at http://gsvadvisors. com/wordpress/wp-content/uploads/2012/04/GSV-EDUFactbook-Apr-13-2012.pdf (accessed on 19 June 2015)

Hammermesh DS (1994) Aging and productivity, rationality and matching: evidence from economists. NBER Working Paper No. 4906. National Bureau of Economic Research, Cambridge, MA

Harrison JL (2006) Post-tenure scholarship and its implications. 17 U. Fla. J.L. \& Pub. Pol'y 139. Available at http:// scholarship.law.ufl.edu/facultypub/86

Henry JB (1980) The tenured professor syndrome. J Med Educ 55:449-451

Holley JW (1977) Tenure and research productivity. Res Higher Educ 6:181-192

Horn M (2009) The case for tenure. Academic Matters Oct/Nov 2009:5-9

ILO (International Labour Organization) (2015) World employment social outlook - the changing nature of jobs. Available at www.ilo.org/wcmsp5/groups/public/ ---dgreports/---dcomm/---publ/documents/publication/ wcms_368626.pdf (accessed on 19 June 2015)

Kaplan K (2010) The changing face of tenure. Nature 468 : 123-125

Karran T (2007) Academic freedom in Europe: a preliminary comparative analysis. High Educ Policy 20:289-313

Katz DA (1973) Faculty salaries, promotions, and productivity at a large university. Am Econ Rev 63:469-477

Kaufman RR (2007) Factors that influence the publishing productivity of faculty in physical therapist education programs. PhD dissertation, University of Massachusetts, Amherst, MA

Laurance WF, Useche DC, Laurance SG, Bradshaw CJA (2013) Predicting publication success for biologists. Bioscience 63:817-823

Leung W (2009) Job security and productivity: evidence from academics. Masters thesis, University of California, Berkeley, CA

Levin SG, Stephan PE (1991) Research productivity over the 
life cycle: evidence for academic scientists. Am Econ Rev 81:114-132

Lynch K (2014) New managerialism, neoliberalism and ranking. Ethics Sci Environ Polit 13:141-153

Nelson C (2010) No university is an island - saving academic freedom. New York University Press, New York, NY

Nelson C (2012) Should tenure for college professors be abolished? No. Wall Street Journal. Available at www. wsj.com/articles/SB1000142405270230361050457741829 3114042070 (accessed on 15 June 2015)

Neumann Y (1979) Research productivity of tenured and nontenured faculty in US universities: a comparative study of four fields and policy implications. J Educ Adm 17:92-101

Pager T (2013) Tenure study co-authored by Morton Schapiro sparks controversy. The Daily Northwestern, 8 October 2013. Available at http://dailynorthwestern. com/2013/10/08/campus/tenure-study-co-authored-bymorton-schapiro-sparks-controversy/ (accessed on 15 June 2015)

Pain E (2015) Aligning career expectations with academic reality. Science Careers. Available at http://sciencecareers. sciencemag.org/career_magazine/previous_issues/articles/ 2015_06_10/caredit.a1500150 (accessed on 19 June 2015)

Pauly D (2015) Tenure, the Canadian tar sands and 'ethical oil'. Ethics Sci Environ Polit 15:55-57

Petersen AM, Wang F, Stanley HE (2010) Methods for measuring the citations and productivity of scientists across time and discipline. Phys Rev E Stat Nonlin Soft Matter Phys 81:036114

Peterson PE (2014) The public turns against teacher tenure. Wall Street Journal, 19 August 2014. Available at www.wsj.com/articles/paul-e-peterson-the-public-turns- against-teacher-tenure-1408420803 (accessed on 15 June 2015)

Rees A, Smith SP (1991) Faculty retirement in the arts and sciences. Princeton University Press, Princeton, NJ

Riley NS (2012) Should tenure for college professors be abolished? Yes. Wall Street Journal. Available at www. wsj.com/articles/SB1000142405270230361050457741829 3114042070 (accessed on 15 January 2015)

Robinson D (2014) The mismeasure of higher education? The corrosive effect of university rankings. Ethics Sci Environ Polit 13:65-71

Rørstad K, Aksnes DW (2015) Publication rate expressed by age, gender and academic position - a large-scale analysis of Norwegian academic staff. J Informetrics 9:317-333

Stergiou KI, Lessenich S (2014) On impact factors and university rankings: from birth to boycott. Ethics Sci Environ Polit 13:101-111

Stergiou KI, Tsikliras AC (2014) Global university rankings uncovered: introduction. Ethics Sci Environ Polit 13: $59-64$

Stratilatis C (2014) University rankings and the scientification of social sciences and humanities. Ethics Sci Environ Polit 13:177-192

Tsikliras AC, Robinson D, Stergiou KI (2014) Which came first: the money or the rank? Ethics Sci Environ Polit 13: 203-213

Wetherbe JC (2012) Why I have a big problem with academic tenure. Businessweek. Available at www. businessweek.com/articles/2012-12-28/why-i-have-abig-problem-with-academic-tenure (accessed on 15 June 2015)

Wetherbe JC (2013) It's time for tenure to lose tenure. Harvard Business Review. Available at https://hbr.org/2013/ 03/its-time-for-tenure-to-lose-te/ (accessed on 15 June 2015)

Appendix 1. No. of universities per Quacquarelli Symonds (QS) worldwide ranking class by discipline (top) and by region (bottom)

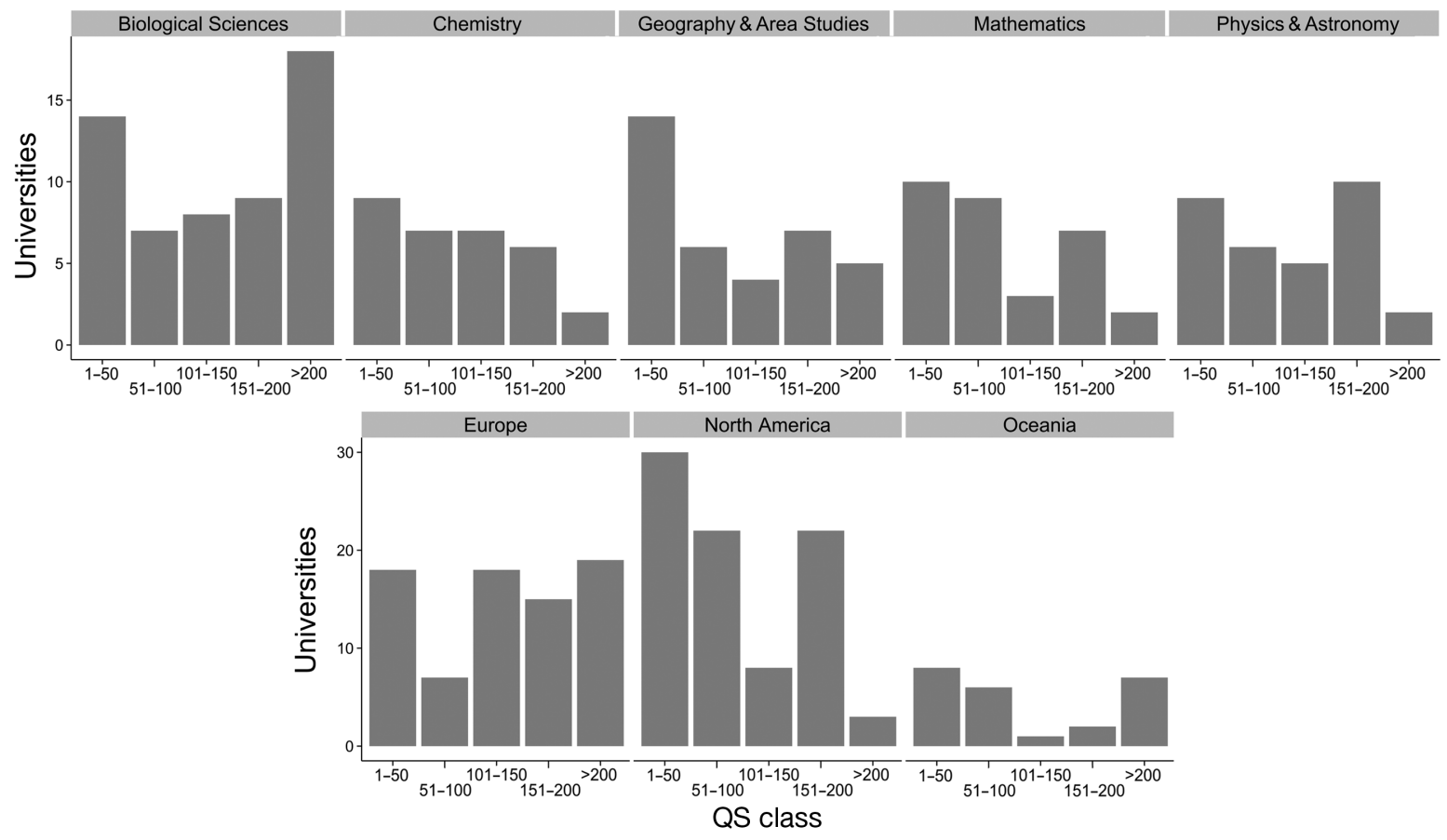

